\title{
Genetic Variability and Interrelationship Analyses for Quantitative Traits in Elite Germplasm of Rice (Oryza sativa L.)
}

\author{
M. Setty ${ }^{*}$ B. G. Suresh and S. G. Pasha \\ Department of Genetics and Plant Breeding, Naini Agriculture Institute, \\ SHUATS, Prayagraj, U.P, India \\ *Corresponding author
}

\section{A B S T R A C T}

Keywords

Variability parameters, Correlation coefficient, Path analysis, Rice (Oryza sativa L.)

Article Info

Accepted:

04 November 2019

Available Online:

10 December 2019
The present investigation was carried out to assess the genetic variability parameters, correlation and path analysis in 32 rice elite germplasm for 13 yield and its contributing traits during kharif 2018 at Field Experimentation Centre, Department of Genetics and Plant Breeding, Naini Agricultural Institute, Sam Higginbottom of Agriculture, Technology and Sciences, Uttar Pradesh in Randomized Block Design, replicated thrice. The analysis of variance for mean sum of squares due to genotypes showed significant differences for all the quantitative characters studied at $1 \%$ level and $5 \%$ level of significance. PCV and GCV was found high for traits like number of tillers per hill, number of panicle per hill, biological yield, harvest index and grain yield per hill. The difference between Phenotypic Coefficient of Variation and Genotypic Coefficient of Variation was low for days to $50 \%$ flowering, plant height, number of spikelet's per panicle and days to maturity traits indicating less influenced by the environment. The characters like number of tillers per hill, number of panicle per hill, biological yield and grain yield per hill showed high heritability coupled with high genetic advance as percentage of mean indicating the preponderance of additive gene action. The grain yield per plant had highly significant and positive correlation both at genotypic and phenotypic levels with number of tillers per hill, number of spikelet's per hill and harvest index, high direct effects of these characters appeared to be the main reason for their strong association with grain yield. Hence, direct selection for these characters would be very effective for further improvement of grain yield in rice and for development of hybrids in crop improvement programmes.

\section{Introduction}

Rice (Oryza sativa, $2 \mathrm{n}=24)$ is world's important staple cereal food crop growing in at least 114 countries under diverse conditions (Pandey et al., 2010). The rice plant belongs to the genus Oryza, sub tribe Oryzineae of the family Gramineae. This genus has 24 species, of which 22 are wild and two, viz. O. sativa and $O$. glaberrima, are cultivated. Rice is the longest continuously grown cereal crop in the world according to International Rice Research Institute (IRRI). Rice is known as the "Grain of life" and synonymous with food 
for Asians as it supplies starch, protein and micronutrients. The average percent of protein in rice grain is 8 percent, iron $1.2 \mathrm{mg}$ and zinc $0.5 \mathrm{mg}$. The amino acid profile shows that rich it is rich in glutamic acid and aspartic acid, highest quality cereal protein rich in lysine (3.8\%) FAO - 2013.

Globally rice is cultivated now 154 million hectares with annual production of around 600 million tonnes and average productivity of 3.9 tonnes per hectare. More than $90 \%$ of this produced and consumed in Asian countries shares the world is $21.6 \%$ rice production.

India stands first in area (43.97 m.ha) and world's second largest producer (109.32 Mt) of rice after china with the productivity of 2.55 tons per hectare.

The year 2016-17 recorded the highest rice production (109.32) still now. It is estimated that in India, the demand for rice will be 129.6 million tons by 2040 and 137.3 million tons by 2050 for internal consumption. (Directorate of Economics and Statistics, 2016 -17).

To increase the production, a critical analysis of genetic variability, heritability and genetic advance for quantitative traits components is essential for effective genetic improvement along with the estimation of nature of character associations of yield and yield attributing traits by means of correlation coefficients and assessment of the direct and indirect contribution of yield components on grain yield through path-coefficient analysis is a pre-requisite for initiating any crop improvement programme and for adoption of appropriate selection techniques Singh et al., (2018). Therefore, the objective of this study was to assess the genetic variability, heritability and genetic advance of yield and yield associated traits in some promising rice genotypes to assist the future breeding programs for better yield improvement.

\section{Materials and Methods}

The present investigation was carried out at Field Experimentation Centre of Department of Genetics and Plant Breeding, SHUATS, Prayagraj (U.P.) during Kharif-2018. This comprised of 32 rice genotypes which were obtained from Department of Genetics and Plant Breeding, SHUATS, Prayagraj (U.P.) and raised in Randomized Block Design with three replications. The recommended packages of practices were followed to ensure a good crop stand. The observations for all traits were recorded on five randomly selected plants for each entry in each replication for 13 quantitative traits viz., days to $50 \%$ flowering, plant height, flag leaf length, flag leaf width, number of tillers per hill, number of panicle per hill, panicle length, number of spikelet's per panicle, days to maturity, biological yield, harvest index, test weight and grain yield per hill were recorded per plot through judgmental sampling.

The data was analyzed and interrelationships among traits values were estimated using software INDOSTAT. Differences were declared statistically significant at $\mathrm{P}<0.05$. In this study, phenotypic coefficient of variation (PCV) and genotypic coefficient of variation (GCV) were calculated by the formula given by Burton and Devane (1953). Heritability in broad sense (h2) and genetic advance as percent of mean were estimated by the formula as suggested by Johnson et al., (1955). The correlation coefficient among pairs of characters was calculated according to the formula suggested by Searle (1961). To test the significance of correlation coefficients, the estimated values were compared with the table value (statistical table by Fisher and 1963) at n-2 degrees of freedom (where $n$ denotes the number of genotypes tested) at $5 \%$ and $1 \%$ level of significance. Path coefficient analysis was done to partition the total correlation into direct and indirect effects due 
to the dependent variable and was calculated by the formula suggested by Dewey and Lu (1959).

\section{Results and Discussion}

The mean sum of square due to the treatments showed significant difference among all the genotypes at $5 \%$ level of significance and $1 \%$ level of significance for all the characters. Indicating that these genotypes were genetically variant from each other and similar findings were reported by Rahman (2012) and Paikhomba et al., (2014), Rashmi et al., (2017).

The estimates of PCV and GCV in (Table 1) were found high $(>20)$ for number of tillers per hill, number of panicles per hill, biological index, harvest index and grain yield per hill, these were found similar with results of Padmaja et al., (2008) and ubarhande et al.,(2009). Moderate PCV and GCV were recorded for flag leaf length, flag leaf width, panicle length and test weight and low PCV and GCV were recorded for days to $50 \%$ flowering, plant height, number of spikelet's per panicle and days to maturity, these results were found similar with Islam et al., (2015), kalpana et al., (2018), Devi et al., (2017) and Idris et al., (2013).

Heritability in broad sense was found to be high $(>60 \%)$ for all the characters except for harvest index. High heritability (>60\%) coupled with high genetic advance as percent mean $(>30 \%)$ was recorded for number of tillers per hill $(60.62,43.44)$, number of panicles per hill $(84.99,57.92)$, biological yield $(83.16,56.73)$ and grain yield per hill (73.75, 50.87). Therefore indicating a predominance of additive gene effects and the possibilities of effective selection can be conducted based on these traits for crop improvement program. Similar findings were reported by Sharma and Sharma (2007), sinha et al., (2004), Rai et al., (2014) and Nuruzzaman et al., (2017). Thus these characters offer the best possibility of improvement through selection procedures.

For achieving rational improvement in yield and its related parameters, knowledge on mechanism of correlation, cause and effect relationship provides a basis for formulating suitable selection methods for the yield

In this present investigation in (Table 2) plant height $\left(\mathrm{rp}=0.044^{* *}, \mathrm{rg}=0.096^{*}\right)$, flag leaf length $\left(\mathrm{rp}=0.063^{* *}, \mathrm{rg}=0.003^{*}\right)$, flag leaf width $\left(\mathrm{rp}=0.155^{* *}, \mathrm{rg}=0.082 *\right)$, number of tillers per hill ( $\left.\mathrm{rp}=0.341^{* *}, \quad \mathrm{rg}=0.289^{* *}\right)$, number of spikelet's per panicle $(\mathrm{rp}=0.274 * *$, $\left.\mathrm{rg}=0.229^{*}\right)$, biological yield $(\mathrm{rp}=0.584 * *$, $\left.\mathrm{rg}=0.567^{* *}\right)$ and harvest index $\left(\mathrm{rp}=0.461^{* *}\right.$, $\mathrm{rg}=0.512 * *)$ show significant positive correlation with grain yield per plant at both phenotypic (rp) and genotypic (rg) levels, as yield is a dependent character, the performance of these quantitative characters will also affect the grain yield per plant.

While the above selective characters will indicate that an improvement in these traits will increase the grain yield in rice. Therefore any perspective changes in these characters would also affect the yield in the desirable direction of the objective. These observations are in conformity with the findings of Sharma and Sharma (2009), Subudhi and Dikshit (2009), Rajendra et al., (2017) and Rashid et al., (2014).

Path analysis provides statistical technique for formulating efficient selection strategy. Which helps in determining the characters identified as direct and indirect yield contributing traits and should be given due consideration while devising selection strategy for developing better varieties (Table 3 ). 
Table.1 Estimates of range, mean, coefficient of variation, heritability, genetic advance, genetic advance as \% of mean

\begin{tabular}{|c|c|c|c|c|c|c|c|}
\hline \multirow[t]{2}{*}{ Characters } & \multirow[t]{2}{*}{ Range } & \multirow[t]{2}{*}{ Mean } & \multicolumn{2}{|c|}{ Coefficient of Variation } & \multirow{2}{*}{$\begin{array}{l}\text { Heritability } \\
\text { (bs) } \%\end{array}$} & \multirow{2}{*}{$\begin{array}{c}\text { Genetic } \\
\text { advance (GA) }\end{array}$} & \multirow{2}{*}{$\begin{array}{c}\text { Genetic advance } \\
\text { as } \% \text { of mean }\end{array}$} \\
\hline & & & GCV & PCV & & & \\
\hline Days to $50 \%$ flowering & $82.00-101.00$ & 89.16 & 5.78 & 5.93 & 94.84 & 10.33 & 11.59 \\
\hline Plant height & $98.81-142.05$ & 113.90 & 8.35 & 8.95 & 87.00 & 18.27 & 16.04 \\
\hline Flag leaf length & $30.09-49.40$ & 39.22 & 13.66 & 15.22 & 80.56 & 9.91 & 25.26 \\
\hline Flag leaf width & $1.27-2.23$ & 1.61 & 13.65 & 14.86 & 84.31 & 0.41 & 25.82 \\
\hline Number of tillers per hill & $6.60-19.40$ & 11.33 & 27.09 & 34.79 & 60.62 & 4.92 & 43.44 \\
\hline Number of panicle per hill & $5.00-15.33$ & 8.38 & 30.50 & 33.09 & 84.99 & 4.86 & 57.92 \\
\hline Panicle length & $19.10-33.00$ & 27.38 & 12.11 & 14.01 & 74.77 & 5.91 & 21.58 \\
\hline Number of spikelet's per panicle & $104.33-160.67$ & 124.79 & 9.47 & 10.58 & 80.14 & 21.80 & 17.47 \\
\hline Days to maturity & $116.00-134.00$ & 125.33 & 5.04 & 5.12 & 96.70 & 12.79 & 10.20 \\
\hline Biological yield & $16.80-91.40$ & 59.66 & 30.20 & 33.12 & 83.16 & 33.85 & 56.73 \\
\hline Harvest index & $16.02-55.45$ & 40.53 & 20.32 & 26.57 & 58.45 & 12.97 & 32.00 \\
\hline Test weight & $20.08-38.26$ & 29.26 & 13.40 & 13.44 & 99.39 & 8.05 & 27.51 \\
\hline Grain yield per hill & $11.07-36.20$ & 23.88 & 28.75 & 33.48 & 73.75 & 12.15 & 50.87 \\
\hline
\end{tabular}


Table.2 Phenotypic (rp) and Genotypic (gp) correlation coefficient between yield and its component traits of rice genotypes

\begin{tabular}{|c|c|c|c|c|c|c|c|c|c|c|c|c|c|c|}
\hline Characters & & $\begin{array}{c}\text { Days to } \\
50 \% \\
\text { flowering }\end{array}$ & $\begin{array}{l}\text { Plant } \\
\text { height }\end{array}$ & $\begin{array}{l}\text { Flag } \\
\text { leaf } \\
\text { length }\end{array}$ & $\begin{array}{c}\text { Flag } \\
\text { leaf } \\
\text { width }\end{array}$ & $\begin{array}{c}\text { Number } \\
\text { of tillers } \\
\text { per hill }\end{array}$ & $\begin{array}{c}\text { Number } \\
\text { of panicle } \\
\text { per hill }\end{array}$ & $\begin{array}{l}\text { Panicle } \\
\text { length }\end{array}$ & $\begin{array}{l}\text { Number of } \\
\text { spikelet's } \\
\text { per panicle }\end{array}$ & $\begin{array}{l}\text { Days to } \\
\text { maturity }\end{array}$ & $\begin{array}{c}\text { Biological } \\
\text { yield }\end{array}$ & $\begin{array}{c}\text { Harvest } \\
\text { index }\end{array}$ & $\begin{array}{c}\text { Test } \\
\text { weight }\end{array}$ & $\begin{array}{c}\text { Grain } \\
\text { yield per } \\
\text { plant }\end{array}$ \\
\hline \multirow{2}{*}{$\begin{array}{l}\text { Days to } 50 \% \\
\text { flowering }\end{array}$} & rg & 1.00 & $0.262 * *$ & $0.309^{* *}$ & $0.210^{*}$ & 0.158 & 0.023 & $-0.212 *$ & 0.08 & $0.249^{*}$ & $0.372^{* *}$ & $-0.462 * *$ & $-0.216^{*}$ & 0.057 \\
\hline & rp & 1.00 & $0.244^{*}$ & $0.273^{* *}$ & 0.197 & 0.122 & 0.025 & -0.162 & 0.066 & $0.224^{*}$ & $0.329^{* *}$ & $-0.363 * *$ & $-0.211^{*}$ & 0.067 \\
\hline \multirow[t]{2}{*}{ Plant height } & rg & & 1.00 & $0.385^{* *}$ & $0.529 * *$ & 0.013 & 0.079 & $0.222 *$ & 0.142 & $-0.203^{*}$ & $0.326^{* *}$ & $-0.262 * *$ & 0.023 & $0.044 * *$ \\
\hline & rp & & 1.00 & $0.329 * *$ & $0.481 * *$ & 0.006 & 0.089 & 0.184 & 0.087 & -0.185 & $0.310^{* *}$ & -0.157 & 0.017 & $0.096^{*}$ \\
\hline Flag leaf length & rg & & & 1.00 & $0.653 * *$ & $-0.561 * *$ & $-0.463 * *$ & 0.188 & -0.13 & -0.086 & 0.194 & -0.138 & -0.148 & $0.063 * *$ \\
\hline \multirow[t]{2}{*}{ Flag leaf width } & rg & & & & 1.00 & $-0.456 * *$ & $-0.428 * *$ & $0.252 *$ & $-0.268 * *$ & -0.158 & 0.028 & -0.184 & -0.155 & $0.155^{* * *}$ \\
\hline & rp & & & & 1.00 & $-0.294 * *$ & $-0.360 * *$ & $0.237 *$ & $-0.219 *$ & -0.161 & 0.072 & -0.145 & -0.147 & $0.082 *$ \\
\hline \multirow{2}{*}{$\begin{array}{c}\text { Number of tillers per } \\
\text { hill }\end{array}$} & $\mathrm{rg}$ & & & & & 1.00 & $0.880^{* *}$ & $-0.261 *$ & $0.527 * *$ & $0.274^{* *}$ & $0.370^{* *}$ & -0.024 & -0.034 & $0.341^{* *}$ \\
\hline & rp & & & & & 1.00 & $0.679 * *$ & -0.181 & $0.444^{* *}$ & $0.206^{*}$ & $0.302^{* *}$ & 0.021 & -0.025 & $0.289 * *$ \\
\hline \multirow{2}{*}{$\begin{array}{c}\text { Number of panicle } \\
\text { per hill }\end{array}$} & $\mathrm{rg}$ & & & & & & 1.00 & $-0.251 *$ & $0.473^{* *}$ & -0.127 & $0.331^{* *}$ & $0.229 *$ & -0.107 & 0.497 \\
\hline & rp & & & & & & 1.00 & $-0.231 *$ & $0.444^{* *}$ & -0.108 & $0.333^{* *}$ & 0.106 & -0.098 & 0.398 \\
\hline \multirow[t]{2}{*}{ Panicle length } & $\mathrm{rg}$ & & & & & & & 1.00 & -0.123 & -0.02 & 0.086 & 0.12 & $0.475 * *$ & -0.127 \\
\hline & rp & & & & & & & 1.00 & -0.105 & -0.037 & 0.062 & 0.115 & $0.414 * *$ & 0.112 \\
\hline $\begin{array}{l}\text { Number of spikelet's } \\
\text { per panicle }\end{array}$ & rg & & & & & & & & 1.00 & -0.011 & $0.305^{* *}$ & -0.025 & 0.083 & $0.274 * *$ \\
\hline \multirow[t]{2}{*}{ Days to maturity } & rg & & & & & & & & & 1.00 & 0.047 & -0.13 & -0.045 & 0.087 \\
\hline & rp & & & & & & & & & 1.00 & 0.042 & -0.11 & -0.046 & 0.084 \\
\hline \multirow[t]{2}{*}{ Biological yield } & rg & & & & & & & & & & 1.00 & $-0.437 * *$ & 0.061 & $0.584 * *$ \\
\hline & rp & & & & & & & & & & 1.00 & $-0.363^{* *}$ & 0.053 & $0.567 * *$ \\
\hline \multirow[t]{2}{*}{ Harvest index } & rg & & & & & & & & & & & 1.00 & -0.018 & $0.461^{* *}$ \\
\hline & rp & & & & & & & & & & & 1.00 & -0.01 & $0.512 * *$ \\
\hline \multirow[t]{2}{*}{ Test weight } & rg & & & & & & & & & & & & 1.00 & -0.05 \\
\hline & rp & & & & & & & & & & & & 1.00 & -0.043 \\
\hline \multirow[t]{2}{*}{ Grain yield per plant } & rg & & & & & & & & & & & & & 1.00 \\
\hline & rp & & & & & & & & & & & & & 1.00 \\
\hline
\end{tabular}

** Significance at $1 \%$ and $*$ Significance at $5 \%$ level 
Table.3 Direct (diagonal) and indirect (off diagonal) effect of different traits on yield of rice genotypes

\begin{tabular}{|c|c|c|c|c|c|c|c|c|c|c|c|c|c|c|}
\hline Characters & & $\begin{array}{c}\text { Days to } \\
50 \% \\
\text { flowering }\end{array}$ & $\begin{array}{c}\text { Plant } \\
\text { height }\end{array}$ & $\begin{array}{c}\text { Flag } \\
\text { leaf } \\
\text { length }\end{array}$ & $\begin{array}{c}\text { Flag } \\
\text { leaf } \\
\text { width }\end{array}$ & $\begin{array}{c}\text { Number } \\
\text { of tillers } \\
\text { per hill }\end{array}$ & $\begin{array}{c}\text { Number } \\
\text { of panicle } \\
\text { per hill }\end{array}$ & $\begin{array}{l}\text { Panicle } \\
\text { length }\end{array}$ & $\begin{array}{c}\text { Number of } \\
\text { spikelet's } \\
\text { per panicle }\end{array}$ & $\begin{array}{l}\text { Days to } \\
\text { maturity }\end{array}$ & $\begin{array}{l}\text { Biological } \\
\text { yield }\end{array}$ & $\begin{array}{l}\text { Harvest } \\
\text { index }\end{array}$ & $\begin{array}{c}\text { Test } \\
\text { weight }\end{array}$ & $\begin{array}{c}\text { Grain } \\
\text { yield per } \\
\text { plant }\end{array}$ \\
\hline \multirow{2}{*}{$\begin{array}{l}\text { Days to } 50 \% \\
\text { flowering }\end{array}$} & $\mathbf{G}$ & -0.057 & 0.134 & 0.438 & -0.264 & 1.386 & -0.188 & 0.023 & -0.081 & -0.809 & 0.535 & -1.304 & 0.129 & 0.057 \\
\hline & $\mathbf{P}$ & -0.064 & -0.012 & 0.010 & 0.002 & 0.002 & 0.001 & 0.007 & 0.000 & -0.006 & 0.290 & -0.293 & -0.004 & 0.067 \\
\hline \multirow[t]{2}{*}{ Plant height } & G & -0.015 & -0.511 & 0.547 & -0.665 & 0.115 & -0.657 & -0.024 & -0.144 & 0.660 & 0.469 & -0.739 & -0.014 & $0.044 * *$ \\
\hline & $\mathbf{P}$ & -0.016 & -0.051 & 0.012 & 0.004 & 0.000 & 0.002 & -0.008 & 0.000 & 0.005 & 0.274 & -0.127 & 0.000 & $0.096 *$ \\
\hline \multirow[t]{2}{*}{ Flag leaf length } & $\mathbf{G}$ & -0.018 & 0.197 & -1.418 & -0.820 & -4.919 & 3.834 & -0.020 & 0.132 & 0.280 & 0.279 & -0.388 & 0.089 & $0.063 * *$ \\
\hline & $\mathbf{P}$ & -0.017 & -0.017 & -0.038 & 0.005 & -0.007 & -0.009 & -0.007 & 0.000 & 0.002 & 0.129 & -0.118 & -0.002 & $0.003 *$ \\
\hline \multirow[t]{2}{*}{ Flag leaf width } & $\mathbf{G}$ & -0.012 & 0.271 & 0.926 & -1.256 & -3.996 & 3.542 & -0.027 & 0.270 & 0.511 & 0.041 & -0.518 & 0.093 & $0.155^{* *}$ \\
\hline & $\mathbf{P}$ & -0.013 & -0.025 & 0.020 & -0.009 & -0.005 & -0.008 & -0.011 & 0.000 & 0.004 & 0.064 & -0.117 & -0.003 & $0.082 *$ \\
\hline \multirow{2}{*}{$\begin{array}{c}\text { Number of tillers per } \\
\text { hill }\end{array}$} & $\mathbf{G}$ & -0.009 & 0.007 & -0.796 & 0.573 & 8.763 & -7.289 & 0.028 & -0.532 & -0.890 & 0.532 & -0.067 & 0.020 & $0.341 * *$ \\
\hline & $\mathbf{P}$ & -0.008 & 0.000 & -0.016 & -0.003 & 0.016 & 0.015 & 0.008 & -0.001 & -0.005 & 0.266 & 0.017 & 0.000 & $0.289 * *$ \\
\hline \multirow{2}{*}{$\begin{array}{c}\text { Number of panicle } \\
\text { per hill }\end{array}$} & $\mathbf{G}$ & -0.001 & 0.041 & -0.656 & 0.537 & 7.711 & 8.283 & 0.027 & -0.477 & 0.412 & 0.476 & 0.647 & 0.064 & 0.497 \\
\hline & $\mathbf{P}$ & -0.002 & -0.005 & -0.016 & -0.003 & 0.011 & 0.021 & 0.010 & -0.001 & 0.003 & 0.294 & 0.086 & -0.002 & 0.398 \\
\hline \multirow[t]{2}{*}{ Panicle length } & G & 0.012 & 0.114 & 0.266 & -0.316 & -2.283 & 2.076 & 0.107 & 0.124 & 0.064 & 0.124 & 0.338 & -0.285 & -0.127 \\
\hline & $\mathbf{P}$ & 0.010 & -0.009 & 0.006 & 0.002 & -0.003 & -0.005 & -0.045 & 0.000 & 0.001 & 0.054 & 0.093 & 0.008 & 0.112 \\
\hline \multirow{2}{*}{$\begin{array}{c}\text { Number of spikelet's } \\
\text { per panicle }\end{array}$} & G & -0.005 & 0.073 & -0.185 & 0.337 & 4.615 & -3.919 & 0.013 & 1.009 & 0.034 & 0.438 & -0.070 & -0.050 & $0.274 * *$ \\
\hline & $\mathbf{P}$ & -0.004 & -0.004 & -0.005 & -0.002 & 0.007 & 0.010 & 0.005 & 0.002 & 0.001 & 0.246 & -0.024 & 0.001 & $0.229 *$ \\
\hline \multirow[t]{2}{*}{ Days to maturity } & $\mathbf{G}$ & -0.014 & -0.104 & -0.123 & 0.198 & 2.404 & 1.053 & 0.002 & 0.011 & -3.243 & 0.068 & -0.366 & 0.027 & 0.087 \\
\hline & $\mathbf{P}$ & -0.014 & 0.009 & -0.003 & -0.001 & 0.003 & -0.002 & 0.002 & 0.000 & -0.026 & 0.037 & -0.089 & -0.001 & 0.084 \\
\hline \multirow[t]{2}{*}{ Biological yield } & G & -0.021 & 0.167 & 0.275 & -0.036 & 3.244 & -2.743 & -0.009 & -0.308 & -0.154 & -1.438 & -1.232 & -0.037 & $0.584 * *$ \\
\hline & $\mathbf{P}$ & -0.021 & -0.016 & 0.006 & 0.001 & 0.005 & 0.007 & -0.003 & 0.000 & -0.001 & -0.882 & -0.293 & 0.001 & $0.567 * *$ \\
\hline \multirow[t]{2}{*}{ Harvest index } & G & 0.026 & -0.134 & -0.195 & 0.230 & -0.207 & -1.898 & -0.012 & 0.025 & 0.420 & -0.627 & 2.822 & 0.010 & $0.461 * *$ \\
\hline & $\mathbf{P}$ & 0.023 & 0.007 & -0.005 & -0.001 & 0.003 & 0.002 & -0.005 & 0.005 & 0.002 & -0.320 & 0.807 & -0.018 & $0.512 * *$ \\
\hline \multirow[t]{2}{*}{ Test weight } & G & 0.012 & 0.011 & -0.209 & 0.194 & -0.294 & 0.885 & -0.050 & -0.083 & 0.146 & 0.087 & -0.051 & 0.599 & -0.050 \\
\hline & $\mathbf{P}$ & 0.013 & -0.008 & -0.004 & -0.001 & -0.004 & -0.002 & -0.018 & -0.014 & 0.001 & 0.046 & -0.008 & 0.018 & -0.043 \\
\hline
\end{tabular}

$P=$ Phenotypic level and $G=$ Genotypic level, Genotypic path (Residual effect $=0.27689)$ and Phenotypic path (Residual effect $=0.07708)$ 
Characters like number of number of tillers per hill $(\mathrm{G}=8.763, \mathrm{P}=0.016)$, number of spikelets per panicle $(\mathrm{G}=0.274 * *, \mathrm{P}=0.229 *)$ and harvest index $(\mathrm{G}=2.822, \mathrm{P}=0.807)$ show direct positive significant association with grain yield per plant at the both phenotypic (P) and genotypic $(\mathrm{G})$ levels indicating that these characters would be more effective in selection criteria for developing better varieties. These results were similar with the findings of Srikanth et al., (2017), Rohit et al., (2017), Tefera et al., (2017), Vinoth et al., (2016) and Roy et al., (2015).

From this study, we conclude that the germplasms exhibited a wide range of variability for most of the traits. This ensures the ample scope for selection of promising genotypes from present set of germplasms for yield improvement.

Characters like number of tillers per panicle, number of panicles per hill, biological yield and grain yield per hill showed high heritability coupled with high genetic advance indicating they are less influenced by environment and phenotypic estimates of such traits would be very closely relates to their actual genetic potential which can be further enhanced by means of simple selection and therefore, need top priority during selection.

Based on correlation coefficient and path analysis results number of tillers per hill, number of spikelet's per panicle and harvest index show direct positive significant association with grain yield of the plant and these traits can be used as selection indices for improving yield or for developing better varieties.

\section{Acknowledgement}

The authors are sincerely grateful to the Hon'ble vice-chancellor, Sam Higginbottom University of Agriculture, Technology and
Sciences, Prayagraj, for providing the necessary facilities for completing the research work.

\section{References}

Burton, G.W. and Devane. (1953). Estimation of heritability in tall fescue. Festula arundnacea from replicated clonal material Agronomy, 45 (2): 478-481.

Devi, R.K., Satish, C.B., Lingaiah, N., Hari, Y. and Venkanna, V. (2017). Analysis of variability, correlation and path coefficient studies for yield and quality traits in rice (Oryza sativa L.). Agricultural science digest, 37 (1): 19.

Dewey, D.R and Lu, K.H. (1959). Genetic variability, correlation and path coefficient analysis of components of crested wheat grass seed production. Agronomic Journal, 51 (2): 515-518.

Idris, A.E. and Mohamad, K.A. (2013). Estimation of genetic variability and correlation for grain yield components in rice (Oryza sativa L.). Global Journal of Plant Ecophysiology, 3 (1): 1-6.

Kalpana, K., Thirumeni, S., Vengadessan, V. and Mohamed, Y. (2018). Genetic variability studies for yield and quality traits in rice (Oryza sativa L.). International Journal of Applied Agricultural and Horticultural Sciences, 9 (2): 224-227.

Nuruzzaman, M., Hasan, L., Shamsun, N.B. and Huda, M.H. (2017). Correlation and path coefficient analysis of yield components in NERICA mutant rice lines under rainfed conditions. Journal of Experimental Agriculture International, 16 (1): 1-8.

Rajendra, P.K., Radha, K.V., Sudheer, K.S., Senguttuvel, P. and Rao, L.V.S. (2017). Character association and path analysis studies for quantitative traits 
in hybrid rice. Intrenational Journal of

Pure and Applied Bioscience, 5 (4): 1513-1518

Rashid, K., Kahliq, I., Farooq, M.O. and Ahsan, M.Z. (2014). Correlation and cluster analysis of some yield and yield related traits in rice (Oryza sativa L.). Journal of Recent Advance Agriculture, 2(6): 271-276.

Rohit, Y., Priyanka, R., Verma, O.P., Singh, P.K., Priyansh, S. and Vijayanand, P. (2017). Genetic variability, heritability and genetic advance in rice (Oryza sativa L.) for grain yield and its contributing attributes under sodic soil. Journal of Pharmacognosy and Phytochemistry, 6 (5): 1294-1296.

Roy, B., Lal, G.M. and Sagar, M.C. (2015). Study on genetic variability and path analysis in rice (Oryza sativa L.) hybrids. The Bioscan, 9 (3\&4): 10271032.

Srikanth, T., Sudheer, K.S., Senguttuvel. P. and Seshu, M.M. (2017). Correlation analysis for yield components in rice (Oryza sativa L.). Intrenational Journal of Pure and Applied Bioscience, 5 (4): 1412-1415.

Tefera, A., Sentayehu, A. and Leta, T. (2017). Genetic variability, heritability and genetic advances for yield and its related traits in rainfed lowland rice. Advances in crop science and technology. 5 (2): 1245-1250.

Rai, S.K., Suresh, B.G., Lavanya, G.R., Rai, P.K., Kumar, R. and Sandya. (2014). Genetic variability, correlation and path coefficient studies for grain yield and other yield attributing traits in rice (Oryza sativa L.). International Journal of Life Sciences Research, 2(4): 229-234.

Sinha, S.K., Tripati, A.K., Bisen, U.K. (2004). Study of genetic variability and correlation co-efficient analysis in Mid land landraces of rice. Annals of
Agricultural Research, 25 (1): 1-3.

Pandey, P. and Anurag, P.J. (2010). Estimation of genetic parameters in indigenous rice. $A A B$ Bioflux, 2 (1): 79- 84.

Vinoth, R., Shivaramakrishna, R., Sivaji. M., Tamilkumar, P., Kumar, B. and Marker, S. (2016). Genetic analysis and correlation studies for grain yield in rice (Oryza sativa L.) under the Allahabad agro climatic region. International Journal of Forestry and Crop Improvement, 7 (1): 93-100.

Ubarhande, V. A., Prasad, R., Singh, R. P., Singh, S. P. and Agrawal, R. K. (2009). Variability and diversity studies in rainfed rice (Oryza sativa L.) Indian Journal of Plant genetic Resources 22(2): 134-137.

Sharma, A. K. and Sharma, R. N. (2007). Genetic variability and character association in early maturing rice. Oryza 44 (4): 300-303.

Subudhi, H. N. and Dikshit, N. (2009). Variability and character association of yield components in rainfed lowland rice. Indian Journal of Plant Genetic Resources 2291): 31-35.

Padmaja, D., Radhika, K., Subba Rao, L. V. and Padma, V. (2008). Studies on variability, heritability and genetic advance for quantitative characters in rice (Oryza sativa L.). Indian Journal of Plant Genetic Resources 21(3): 196198.

Fisher, R. A. and Yates, F. (1963). Statistical table for Biological, Agricultural and Medical research. $6^{\text {th }}$ edition. Oliver Boyd Ltd. Edinburgh, pp. 23-85.

Paikhomba, N., Kumar, A., Chaurasia, A. K. and Rai, P. K. (2014). Assessment of Genetic Parameters for Yield Components in Hybrid Rice and Parents. Journal of Rice Research, 2: 117.

Rashmi, D., Saha, S., Loitongbam, B., Singh, 
S. and Singh, P. K. (2017). Genetic variability study for yield and yield components in rice (Oryza sativa L.). International Journal of Agriculture, Environment \& Biotechnology, 10(2): 171 .

Searle, S. R. 1961. Phenotypic, genetic and environmental correlation. Biometrics, 17:474-480.

Johnson, H. N., Robinson, H. F. and Comstock, R. E. 1955. Estimate of genetic and environmental variability in soybean. Agronomy Journal 27: 314-318.

\section{How to cite this article:}

Setty, M., B. G. Suresh and Pasha, S. G. 2019. Genetic Variability and Interrelationship Analyses for Quantitative Traits in Elite Germplasm of Rice (Oryza sativa L.). Int.J.Curr.Microbiol.App.Sci. 8(12): 342-350. doi: https://doi.org/10.20546/ijcmas.2019.812.046 